\title{
IDENTIFIKASI KOMUNIKASI ANAK BERKEBUTUHAN KHUSUS DALAM INTERAKSI SOSIAL
}

\author{
Refiana Ainnayyah \\ Program Bimbingan dan Konseling, Fakultas Ilmu Pendidikan, Universitas Negeri Surabaya \\ refianaany12@gmail.com
}

\author{
Rohma Isni Maulida, Amelia Astian Ningtyas \\ Program Bimbingan dan Konseling, Fakultas Ilmu Pendidikan, Universitas Negeri Surabaya \\ rohmacantik.02@gmail.com, ameliaaningtyas@gmail.com
}

\section{Istiana}

Program Pendidikan Luar Biasa, Fakultas Ilmu Pendidikan, Universitas Negeri Surabaya isti1903@gmail.com

\begin{abstract}
Abstrak
Penelitian ini bertujuan untuk mengetahui dan menjelaskan mengenai bentuk kemampuan komunikasi yang dapat dilakukan anak berkebutuhan khusus (ABK), serta kemampuan komunikasi ABK ketika melakukan interaksi sosial di SMPN 2 Krian. Metode Penelitian ini menggunakan pendekatan kualitatif jenis penelitian studi kasus. Subjek penelitian merupakan anak berkebutuhan khusus yang duduk di kelas VII. Pengumpulan data menggunakan metode observasi, wawancara dan dokumentasi. Data-data yang diperoleh akan dianalisis, data disajikan dengan menarik kesimpulan mengenai pemaknaan data yang telah terkumpul. Hasil penelitian menunjukkan bahwa anak berkebutuhan khusus mampu berkomunikasi dengan baik meskipun sedikit lambat dalam menangkap pesan yang disampaikan dan anak-anak dengan kebutuhan khusus dapat berinteraksi secara sosial dengan lingkungan mereka tetapi tidak dapat dipisahkan dari gangguan yang tidak fokus.
\end{abstract}

Kata Kunci : Kemampuan Komunikasi, Interaksi Sosial, dan Anak Berkebutuhan Khusus

\begin{abstract}
The purpose of this study is to find out and explain the forms of communication skills that can be performed by children with special needs, as well as communication skills when conducting social interactions in 2 krian Junior High School. This research method uses a qualitative approach to the type of case study research. The research subjects were children with special needs who sat in class VII. Data collection uses the method of observation, interviews and documentation. The data obtained will be analyzed, data presented by drawing conclusions regarding the meaning of the data that has been collected. The results of the study showed that children with special needs were able to communicate well even though they were a little slow in capturing the message delivered and children with special needs were able to interact socially with their environment but could not be separated from the disorder that is unfocused.
\end{abstract}

Keywords : Communication Skills, Social Interaction, and Childern With Special Needs 


\section{PENDAHULUAN}

Interaksi sosial penting untuk diajarkan pada anak sejak dini. Interaksi sosial terjadi anata individu dengan individu yang lain. Dengan interaksi sosial secara tidak langsung mengajarkan anak bahwa manusia itu adalah makhluk sosial yang tidak pernah lepas dari lingkungan sosial di sekitarnya.

Yang telah kita ketahui bahwa interaksi yang dilakukan oleh manusia berkaitan dengan komunikasi, yaitu proses penyampaian dan pertukaran pesan. Pada kenyataannya komunikasi dilakukan oleh setiap manusia sejak manusia itu lahir ke dunia dan akan terus berjalan seiring dengan kehidupan manusia itu sendiri.

Komunikasi akan terus dilakukan selama interaksi sosial berlangsung. Manusia selalu menggunakan komunikasi sebagai alat untuk berinteraksi sosial. Namun beberapa orang mengalami gangguan dalam berkomunikasi dengan faktor-faktor gangguan yang berbeda. Salah satunya orang yang mengalami gangguan komunikasi dalam berinteraksi sosial adalah anak berkebutuhan khusus.

Anak berkebutuhan khusus adalah mereka yang memiliki keterlambatan fisik, kognitif, psikologis, maupun emosional. Sehingga dapat dikatakan mereka berbeda dengan anak normal pada umumnya. Anak berkebutuhan khusus tentunya akan mengalami perbedaan komunikasi dengan anak normal lainnya. Anak berkebutuhan khusus cenderung sibuk dengan dirinya sendiri dan tidak memperdulikan orang lain, sehingga gangguan-gangguan yang dialami anak berkebutuhan khusus terkadang tidak dimengerti oleh orang-orang di skitarnya. Anak berkebutuhan khusus memiliki beberapa masalah namun mereka harus tetap mendapatkan pendidikan yang setara dengan anak normal pada umumnya. Sekolah yang dapat menerima anak berkebutuhan khusus adalah sekolah yang menyelenggarakan inklusi, dimana anak berkebutuhan khusus mendapatkan hak yang sama dengan yang lain dalam hal pendidikan, contohnya SMPN 2 Krian.

Di sekolah inklusi tidak hanya terdapat anak berkebutuhan khusus saja melainkan mereka anak normal juga ada. Tentunya dalam sekolah inklusi anak berkebutuhan khusus memiliki perbedaan cara berkomunikasi. Interaksi sosial yang berlangsung akan sedikit berbeda ktika yang berinteraksi adalah anak reguler dan anak berkebutuhan khusus.

Peneliti mengambil fokus masalah penelitian mengenai kemampuan komunikasi dan interaksi sosial pada anak berkebutuhan khusus di SMPN 2 krian. Adapun tujuan dari penelitian mengenai kemampuan komunikasi anak berkebutuhan khusus dalam interaksi sosial adalah untuk mengetahui kemampuan komunikasi anak berkebutuhan khusus dalam interaksi sosial di sekolah SMPN 2 Krian. 


\section{METODE}

Dalam penelitian ini digunakan metode penelitian kualitatif jenis penelitian studi kasus. Bertujuan untuk mengamati gejala-gejala yang ada secara langsung. Metode pengumpulan data dilakukan dengan observasi dan wawancara.

Observasi dilakukan di kelas reguler dan kelas inklusi SMPN 2 krian, data wawancara di dapat dari guru inklusi SMPN 2 Krian. Observasi dan wawancara dilakukan pada tanggal 11 April 2019, di SMPN 2 Krian selama 3 jam. Metode analisis data dilakukan melalui 3 tahap yaitu reduksi data, display data, dan penarikan kesimpulan.

\section{HASIL DAN PEMBAHASAN}

Menurut Rusmita (2011) sebagaimana yang dikutip oleh (Dhiki yulia, 2016) komunikasi verbal yaitu komunikasi yang menggunakan kata-kata dalam penyampaian pesan atau informasinya. Adapun Jenis-jenis Komunikasi Verbal sebagai berikut:

1. Berbicara dan menulis

Berbicara merupakan komunikasi verbal vokal, sedangkan menulis merupakan komunikasi verbal non vokal.

2. Mendengarkan dan membaca

Mendengar dan membaca berbeda, mendengar berarti semata-mata memungut getaran bunyi sedangkan membaca melibatkan empat unsur, yaitu mendengar, memperhatikan, memahami, dan mengingat. Membaca adalah suatu cara untuk mendapatkan informasi dari sesuatu yang ditulis.

Pernyataan ini sejalan bahwa siswa ABK sering berkomunikasi menggunakan kata-kata dalam penyampaian pesan atau informasinya. Selain komunikasi verbal juga ada komunikasi non verbal. Menurut Larry A. Samovar dan Richard E. Porter dalam Deddy Mulyana (2012:343) sebagaimana yang dikutip oleh (Dhiki yulia, 2016) komunikasi non verbal mencakup semua rangsangan (kecuali rangsangan verbal) dalam suatu setting komunikasi, yang dihasilkan oleh individu, yang mempunyai nilai potensial bagi pengirim atau penerima. Menurut Deddy Mulyana (2012:352), sebagaimana yang dikutip oleh (Dhiki yulia, 2016) beberapa jenis komunikasi non verbal sebagai berikut:

1. Sentuhan Sentuhan dapat termasuk salaman, menggenggam tangan, sentuhan di punggung, mengelus-elus, pukulan, dan lain-lain. Masing-masing bentuk komunikasi ini menyampaikan pesan tentang tujuan atau perasaan dari sang penyentuh.

2. Gerakan tubuh Dalam komunikasi non verbal, gerakan tubuh meliputi kontak mata, ekspresi wajah, isyarat, dan sikap tubuh. Gerakan tubuh biasanya digunakan untuk menggantikan suatu kata 
atau frase, misalnya mengangguk untuk mengatakan ya; untuk mengilustrasikan atau menjelaskan sesuatu; menujukkan perasaan. Kontak mata mengacu pada suatu keadaan penglihatan secara langsung antar orang. Melalui kontak mata maka dapat menceritakan kepada orang lain suatu pesan sehingga orang akan memperhatikan kata demi kata melalui tatapan.

3. Proxemik Proxemik yaitu jarak, tempat atau lokasi posisi. Hal ini disebut juga dengan bahasa ruang, yaitu jarak yang digunakan ketka berkomuikasi dengan orang lain, termasuk juga tempat atau lokasi posisi anda berada. Pengaturan jarak menentukan seberapa jauh atau seberapa dekat tingkat keakraban dengan orang lain.

4. Vokalik Vokalik adalah unsur non verbal dalam suatu ucapan, yaitu cara berbicara. Contohnya adalah nada bicara, keras atau lemahnya suara, kecepatan berbicara, kualitas suara, intonasi, dan lain-lain. e. Kronemik Kronemik adalah bidang yang mempelajari penggunaan waktu dalam berkomunikasi non verbal. Penggunaan waktu dalam komunikasi non verbal meliputi durasi yang dianggap cocok bagi suatu aktivitas yang dianggap patut dilakukan dalam jangka waktu tertentu, serta ketetapan waktu. Pernyataan ini tidak sejalan karena siswa ABK dapat berkomunikasi dengan baik menggunakaan kata-kata.

Perilaku tentunya mempengaruhi cara orang berinteraksi sosial. Pengertian dari perilaku itu sendiri adalah segala sesuatu yang dikerjakan, dikatakan, dilhat, dirasakan, didengar dari seseorang atau yang anda lakukan sendiri (Prasetyono, 2008:26). Pernyataan ini sejalan dengan hasil penelitian dimana siswa ABK tidak mengalami gangguan pendengaran namun saat di panggil kadang tidak memperhatikannya.

Hasil penelitian menunjukkan bahwa siswa $\mathrm{ABK}$ termasuk dalam klasifikasi $\mathrm{ABK}$ retardasi mental ringan( kemampuan intelektual di bawah rata-rata) sehingga komunikasinya masih bagus hanya saja kadang-kadang juga tidak fokus jika diajak berkomunikasi. Selain itu juga hasil penelitian menunjukkan bahwa siswa ABK mampu berinteraksi sosial dengan lingkungannya hanya saja kadang ada gangguan yaitu ketidakfokusan.

\section{PENUTUP}

Simpulan

Bentuk kemampuan komunikasi yang dapat dilakukan Abk berupa komunikasi dua arah. ABK bisa menulis dan membaca tetapi kemampuandalam memahami bahasa tulis dalam komunikasi verbal masih kurang. Saat abk merespon dalam komunikasi verbal dan komunikasi non verbal masih memerlukan bimbingan, terkadang Abk mampu merespon tetapi respon yang diberikan belum sesuai dengan topik komunikasi. 


\section{Saran}

Bagi guru kelas diharapkan untuk bekerja sama dengan guru pendamping ABK dan memberikan lebih banyak stimulus agar ABK dapat berkomunikasi dan berinteraksi dalam mengikuti kelas reguler dengan baik

\section{DAFTAR PUSTAKA}

Ahmad Ja'far. 2011. Meningkatkan Kemandirian Interaksi Sosial dan Komunikasi Anak Autis. Skripsi. Yogyakarta: UIN

Burhan Bungin, 2008. Sosiologi Komunikasi. Jakarta: Kencana Prenada Media Group.

Deddy Mulyana. 2012. Ilmu komunikasi Suatu Pengantar. Bandung: PT. Remaja Rosdakarya

Elisa Syafrida, Aryani Tri Wrastari. 2013. Sikap Guru Terhadap Pendidikan Inklusi Ditinjau Dari Faktor Pembentuk Sikap. 2(1), http://journal.unair.ac.id/filerPDF/110810216_Ringkasan.pdf diakses pada tanggal 13 April 2019

Rahayu Fitri. 2014. Kemampuan Komunikasi Anak Autis Dalam Interaksi Sosial (Kasus Anak Autis di Sekolah Inklusi, SD Negeri Giwangan Kotamadya Yogyakarta), Fakultas Ilmu Pendidikan, Universitas Negeri Yogyakarta, Yogyakarta

Rini Darmastuti. 2006. Bahasa Indonesia Komunikasi. Yogyakarta: Gava Media

Suci Ramadian. 2010. Interaksi sosial asosiasif dan disasosiasif. Diakses dari http://www.scrib.com/doc/43122167/interaksi-sosial-asosiatifdan-disasosiatif.html pada tanggal 20 April 2019

Wardani, dkk. 2008. Pengantar Pendidikan Luar Biasa. Jakarta: Universitas Terbuka 